\title{
Profile of the self-medication process and the risks associated with bacterial resistance among undergraduates of the Bachelor's Degree in Pharmacy, at the Academic Center of Vitória de Santo Antão, Pernambuco, in the year 2021
}

\author{
Otacilio Pedro da Silva Neto ${ }^{1 *}$; Maria Stéphanny de Souza Silva ${ }^{2}$; Ana Jhoice de Santana Ferreira ${ }^{3}$; \\ Júlio César da Silva Bruce ${ }^{4}$; Emanuella Barros de Souza Oliveira Álvares ${ }^{5}$ \\ 1 Department of Pharmaceutical Sciences, University Center of Vitória de Santo Antão - UNIVISA, Vitória de Santo Antão, Brazil. \\ 2 Department of Biomedicine, Center for Biomedical Sciences, Federal University of Pernambuco - UFPE, Recife, Brazil. \\ 3 Department of Biomedicine, Center for Biomedical Sciences, Federal University of Pernambuco - UFPE, Recife, Brazil. \\ 4 Department of Pharmaceutical Sciences, University Center of Vitória de Santo Antão - UNIVISA, Vitória de Santo Antão, Brazil. \\ 5 Department of Biology, Center for Biological Sciences, Professor of the Degree Course in Biology, University Center of Vitória de Santo \\ Antão (UNIVISA), Vitória de Santo Antão, Brazil
}

E-mail adresses: otaciliopedroneto2@gmail.com (Otacilio Pedro da Silva Neto), stephanny2018@gmail.com (Maria Stéphanny de Souza Silva), Jhoiceferreira15@gmail.com (Ana Jhoice de Santana Ferreira), juliocesar_9906@hotmail.com (Júlio César da Silva Bruce), emanuella.barros@hotmail.com (Emanuella Barros de Souza Oliveira Alvares )

*Corresponding author

\section{To cite this article:}

Neto, O.P.S.; Silva, M.S.S.; Ferreira, A.J.S.; Bruce, J.C.S.; Álvares, E.B.S.O. Profile of the self-medication process and the risks associated with bacterial resistance among undergraduates of the Bachelor's Degree in Pharmacy, at the Academic Center of Vitória de Santo Antão, Pernambuco, in the year 2021. International Journal of Sciences. Vol. 2, No. 2, 2021, pp. 59-62. ISSN 2763-5392, DOI 000000000000000000

Received: 08 28, 2021; Accepted: 08 30, 2021; Published: 09 06, 2021

\begin{abstract}
Bacterial resistance is a phenomenon that makes bacteria resistant to antibiotics, generating a complicated picture for GlobalHealth, as it becomes increasingly difficult or even impossible to administer the treatment of the infected individual. Therefore, this research aims to analyze the process of self-medication and knowledge about bacterial resistance among undergraduates of the Bachelor's Degree in Pharmacy, from the Academic Center of Vitória de Santo Antão, Pernambuco, in 2021. This is a descriptive exploratory study, in which a questionnaire was applied to students using the online platform Google forms, in which the self-medication profile, most used antibiotic and the main cause of antibiotic use were evaluated. From the above, it was noted the importance of the presence of qualified pharmacists who can act directly in pharmaceutical care and in the counseling of the population through continuing education actions informing about the appropriate use of antimicrobials and bacterial resistance.
\end{abstract}

Keywords: Antibiotics; Self-medication; Bacterial resistance.

\section{Introduction}

It is necessary to understand that bacteria are singlecelled beings that do not present genetic material surrounded by a nuclear membrane and can be found in several morphological forms, such as: coconuts, bacilli, spirrilo, vibrion, among others. In addition, its classification is determined from the constitution of the cell wall, and can be categorized into gram + and gram - [14].

These microorganisms can cause various infections in the individual; however, they can be eliminated with the use of antibiotics. It is noteworthy that each category of the drug 
2 Neto, O.P.S.; Silva, M.S.S.; Ferreira, A.J.S.; Bruce, J.C.S.; Alvares, E.B.S.O. Profile of the self-medication process and the risks associated with bacterial resistance among undergraduates of the Bachelor's Degree in Pharmacy...

acts in local distinctions of the bacterium, such as inhibition of cell wall synthesis, inhibition of DNA synthesis, inhibition of protein synthesis, among others, with the objective of inhibiting the growth process of bacteria, characterized as bacteriostatic antibiotics, or causing their death, in this case are considered antibiotics $[3 ; 9 ; 14]$.

It is important to highlight that sulfonamide $s$ were considered the first class of antibiotics of systemic action, even having a low spectrum of action, contudo, the great milestone of antimicrobials had already been known in 1928 with the discovery of penicillin - antibiotic of natural origin - but was only entered on the market as a therapeutic agent in 1940. Thus, the discovery of antibiotics such as penicillin revolutionized the scenario of death since it could be used in soldiers in the war, preventing infections, women in the postpartum period who died due to puerperal fever caused by the bacterium Streptococcus, among other cases of infection [4;8].

In addition, penicillin began to be used for other purposes such as pain in general and fever, generating the first strains resistant to this antibiotic. Thus, it is worth mentioning that antimicrobials are at the top of the list of the most prescribed in the world and the misuse of this drug generates bacterial resistance $[4 ; 6 ; 8]$.

Bacterial resistance is a phenomenon that makes bacteria resistant to antibiotics, generating a very critical picture for global health as it becomes increasingly difficult or even impossible to treat the infected individual. The main cause of this problem is the indiscriminate use of the antibiotic, that is, not performing the end of the treatment correctly, taking the drug on its own, not making use of the drug at the correct times, incorrect dispensing or even the wrong prescription performed by the doctor $[1 ; 6]$.

In this sense, the World Health Organization states that the bacteria that have resistant strains are: Escherichia coli, Klebsiella pneumoniae, Staphylococcus aureus, Streptococcus pneumoniae and Salmonella spp. It is essential to emphasize that pharmacies do not only act in the sale of medicines, but also in the advice of the population, since the pharmacist is directly linked to the dispensing of medicines and has the responsibility to evaluate the veracity of the prescription and guide the patient according to the correct use of the drug. In this sense, the treatment of an individual is carried out collectively, that is, physicians performing anamnesis together with the appropriate therapeutic indication, pharmacists in the correct dispensing and dosage, in addition to awareness about compliance with treatment and put an end to the population [2; $6 ; 8]$.

With this, this research aims to analyze the process of self-medication and knowledge about bacterial resistance among undergraduates of the Bachelor's Degree in Pharmacy, from the Academic Center of Vitória de Santo Antão, Pernambuco, in 2021.

\section{Methodology}

This is a descriptive exploratory study, due to the current problem with the COVID-19 virus the research was carried out through the evaluation of the electronic questionnaires applied by the Google forms platform.

The electronic questionnaire was directed to the students of Bachelor Pharmacy course of the University Center of Vitória de Santo Antão, in 2021. In which the main variables analyzed were self-medication and understanding about bacterial resistance. After applying the questionnaire, the data obtained were transferred to the Microsoft Excel 2013 version program in which the database was mounted and the statistical analysis of mean and proportion was performed.

In addition, because it is a research with primary data, the present study was submitted to the Ethics Committee on Research with Human Beings of the University Center of Vitória de Santo Antão - UNIVISA and was approved under the opinion of number 47374921.1.0000.9227. The research was carried out after approval of the Ethics Committee and signature of the Free and Informed Consent Term - TCLE which was also provided electronically.

\section{Results and discussion}

After applying the questionnaires, 120 answers were collected, however, after analyzing the results, it was found that 04 students did not sign the Free and Informed Consent Form and 02 students had already completed their pharmacy graduation. Therefore, there were 114 responses in which the vast majority were students enrolled in the 10th period, representing $19.2 \%$ of the answers (Figure 1).

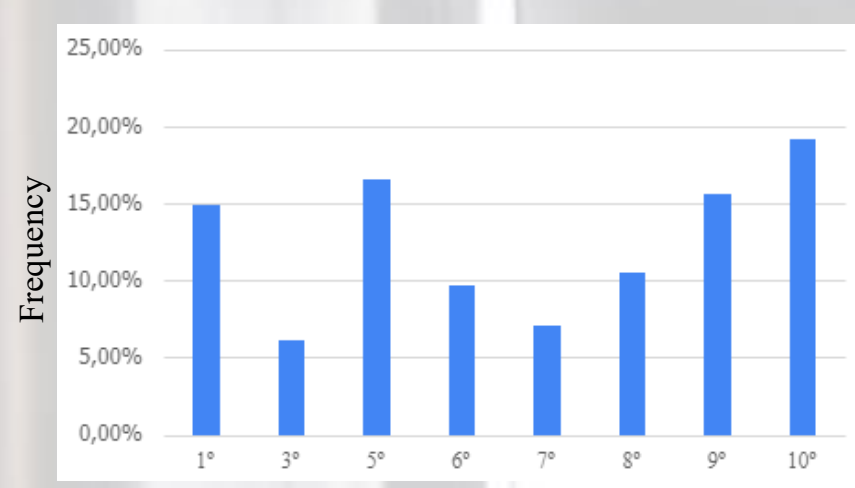

Periods

Figure 1. Distribution by period of the students of the Bachelor of Pharmacy course of the University Center of Vitória de Santo Antão - UNIVISA. Source: Author

It has been shown that $93.8 \%$ of the students understand about bacterial resistance, in which $61.4 \%$ have used antibiotics throughout their lives and that only $4.3 \%$ of them do not comply with the therapeutic protocol and $22.8 \%$ reported discontinuation of treatment after symptom relief (Table 1). It is known that the high consumption of antibiotics and their use indiscriminate form is the major problem for the emergence of bacterial resistance. In this sense, it is noted the 
importance of pharmacists regarding the guidance of the public on the proper use of these drugs, since in many moments the prescription may contain the incorrect therapeutic protocol. Therefore, it is perceived that the results of this research were promising, since the students demonstrated understanding about bacterial resistance and how to prevent its emergence, in which they demonstrated this by performing the correct use of antibiotics $[10 ; 13]$.

Table 1: Variables analyzed with the application of the questionnaire.

\begin{tabular}{|c|c|c|c|c|}
\hline Variables & \multicolumn{2}{|c|}{$\mathbf{N}$} & \multicolumn{2}{|c|}{$\%$} \\
\hline $\begin{array}{l}\text { Lifetime antibiotic } \\
\text { intake. }\end{array}$ & $\begin{array}{c}\text { Yes } \\
70\end{array}$ & $\begin{array}{l}\text { No } \\
44\end{array}$ & $\begin{array}{c}\text { Yes } \\
61,4 \%\end{array}$ & $\begin{array}{c}\text { No } \\
38,6 \%\end{array}$ \\
\hline $\begin{array}{l}\text { Respect the } \\
\text { therapeutic protocol. }\end{array}$ & $\begin{array}{l}\text { Yes } \\
109 \\
\end{array}$ & $\begin{array}{c}\text { No } \\
5\end{array}$ & $\begin{array}{c}\text { Yes } \\
95,7 \% \\
\end{array}$ & $\begin{array}{c}\text { No } \\
4,3 \% \\
\end{array}$ \\
\hline $\begin{array}{c}\text { Discontinue } \\
\text { treatment after } \\
\text { symptom relief. }\end{array}$ & $\begin{array}{l}\text { Yes } \\
26\end{array}$ & $\begin{array}{l}\text { No } \\
88\end{array}$ & $\begin{array}{c}\text { Yes } \\
22,8 \%\end{array}$ & $\begin{array}{c}\text { No } \\
77,2 \%\end{array}$ \\
\hline $\begin{array}{l}\text { Use of antibiotics by } \\
\text { indication of family } \\
\text { and friends. }\end{array}$ & $\begin{array}{l}\text { Yes } \\
83\end{array}$ & $\begin{array}{l}\text { No } \\
31\end{array}$ & $\begin{array}{c}\text { Yes } \\
72,8 \%\end{array}$ & $\begin{array}{c}\text { No } \\
27,2\end{array}$ \\
\hline $\begin{array}{c}\text { You've heard of } \\
\text { bacterial resistance. }\end{array}$ & $\begin{array}{l}\text { Yes } \\
107 \\
\end{array}$ & $\begin{array}{c}\text { No } \\
7 \\
\end{array}$ & $\begin{array}{c}\text { Yes } \\
93,8 \% \\
\end{array}$ & $\begin{array}{c}\text { No } \\
6,2 \% \\
\end{array}$ \\
\hline Total & \multicolumn{2}{|c|}{114} & \multicolumn{2}{|c|}{$100 \%$} \\
\hline
\end{tabular}

In addition, $72.8 \%$ of the students have already used antibiotics through the indication of family and friends (Table 1). It is necessary to understand that studies indicate that the practice of self-medication in lay people is lower than in educated individuals, which justifies the $72.8 \%$ of students who used antibiotics by indication of family in friends, in this sense the high level of education is a predictive factor of self-medication. It is worth mentioning female individuals make more indiscriminate use of antibiotics and this practice may be directly related to the female menstrual cycle, since hormonal changes occur and low immunity occurs. However, the relationship between gender and self-medication was not evaluated in this study $[7 ; 15]$.

IN addition, amoxicillin was the most used antibiotic, as shown in Figure2, representing $44.7 \%$ of the responses, corroborating the study conducted by Marques, Calil and Pacca (2020). It is interesting to understand that this class of antibiotics is known as $\beta$-lactams due to the presence of a $\beta$ lactam ring in its structure, in which it is fundamental in the action of these antibiotics. In this sense, the main mechanism of action of bacterial resistance in these drugs is directly linked with this structure, causing the opening of this ring [5].

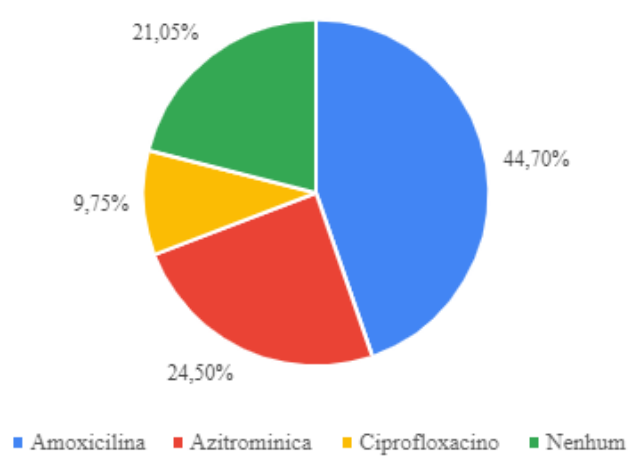

Figure 2. Distribution of the most commonly used antibiotics. Source: Author

However, it is worth mentioning that the reasons for the high consumption of amoxicillin, indiscriminately, were not scored in this study, however, several reasons may be associated with problematic. Therefore, it is believed that one of the reasons is related to the use of $\beta$-lactams as firstclass drugs for most bacterial infections, that is, because it is in the daily life of the population, amoxicillin is usually the antibiotic most indicated by family members, friends or even in pharmacies that sell antibiotics without a prescription [5; 15].

As shown in Figure 3, the sore throat $(62.2 \%)$ was the major cause that led the participants to use the antibiotic, corroborating again the study conducted by Marques, Calil and Pacca (2020). This finding is associated with the beneficial effect of the antibiotic the inflamed throat, either in the reduction of pus present at the site due to inflammation or in the reduction of symptoms, and due to the knowledge of the population about this effect and the sale of these overthe-counter drugs in some drugstores and pharmacies, there is an increase in their consumption and consequently an increase in resistant strains [12].

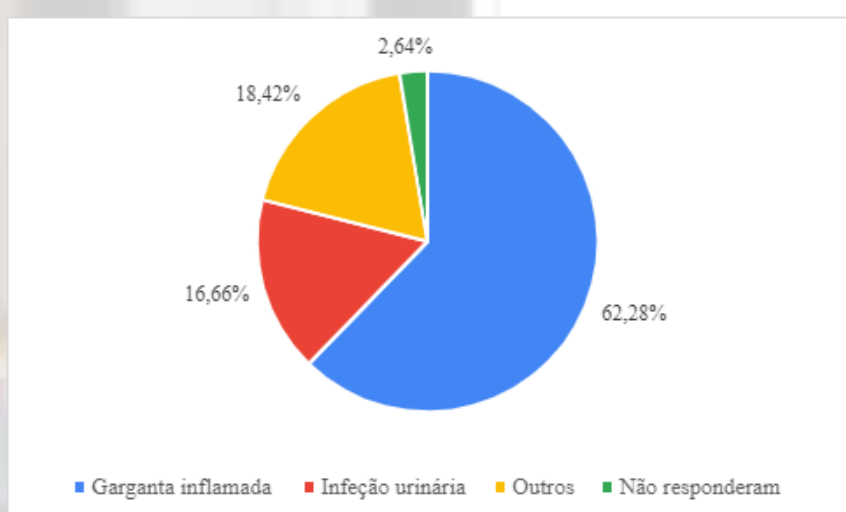

Figure 3. Distribution of the main causes that generate the use of antibiotics. Source: Author

\section{Conclusions}

The emergence of antibiotics has increased the scenario of infections in relation to the treatment of wounds and sick 
4 Neto, O.P.S.; Silva, M.S.S.; Ferreira, A.J.S.; Bruce, J.C.S.; Alvares, E.B.S.O. Profile of the self-medication process and the risks associated with bacterial resistance among undergraduates of the Bachelor's Degree in Pharmacy...

individuals, thus increasing life expectancy. However, its use indiscriminately generated a major public health problem that was the emergence of antibiotic-resistant strains, a phenomenon that hinders the treatment of an individual affected by a bacterial infection.

In this sense, one of the main mechanisms for the occurrence of bacterial resistance is the indiscriminate use of antibiotics, such as: self-medication and not respecting the therapeutic protocol. However, it should be understood that this problem is also associated with the wrong prescription (dosage, schedules and period of treatment) along with incorrect dispensing, in addition to the fact that several pharmacies and drugstores perform sales without medical prescription, thus increasing the rate of self-medication.

Therefore, it is noted that the importance of qualified pharmacists who can act directly in pharmaceutical care, since in addition to dispensing, these professionals act in the counseling of the population through continuing education actions, assisting about the proper use of antimicrobials. In addition, information should be shared in the daily life of the population about the problems that bacterial resistance can generate and ways to prevent these complications from occurring.

\section{Acknowledgments}

Above all I thank God for the opportunity to be here today, my mother who fought every day with me to complete graduation, my advisor put to accept to carry out this research with me and my fiancée who has always been with me supporting me so that I could get to here.

\section{References}

[1] AL BAZ, M.; LAW, M.R.; SAADEH, R. Antibiotics use among Palestine refugees attending UNRWA primary health care centers in Jordan - A cross-sectional study, Travel Medicine and Infectious Disease, 2018.

[2] AHIABU, Mary-Anne; MAGNUSSEN, Pascal; BYGBJERG, Ib Christian; TERSBØL, Britt Pinkowski. Treatment practices of households and antibiotic dispensing in medicine outlets in developing countries: the case of Ghana. Research in Social and Administrative Pharmacy, [S.L.], v. 14, n. 12, p. 1180-1188, dez. 2018.

[3] Costa, A. L. P.; SIlva J. A. C. S. Resistência bacteriana aos antibióticos e Saúde Pública: uma breve revisão de literatura. Estação Científica (UNIFESP), [S.L.], v. 7, n. 2, p. 45-57, 23 ago. 2017.

[4] DOS SANTOS, Alan Pereira et al. Uso indiscriminado de antibióticos pelos estudantes de uma Universidade do Nordeste de Minas Gerais, 2017.

[5] GUIMARÃES, D. O.; MOMESSO, L. S.; PUPO, M. T. Antibióticos: importância terapêutica e perspectivas para a descoberta e desenvolvimento de novos agentes. Quim Nova, v. 33, n. 3, p. 667-679, 2010.
[6] KHALID, L; MAHSOOD, N; ALI I. The Public Health Problem of OTC Antibiotics in Developing Nations, Research in Social \& Administrative Pharmacy, 2016.

[7] KLEMENC-KETIS Z, HLADNIK Z, KERSNIK J. Automedicação entre estudantes da área de saúde e não da Universidade de Ljubljana, Eslovênia. Med Princ. Pract. 2010; 19 (5): 395401.

[8] LIMA, Camila Correa; BENJAMIM, Sandra Cristina Calixto; SANTOS, Rosana Francisco Siqueira dos. MECANISMO DE RESISTÊNCIA BACTERIANA FRENTE AOS FÁRMACOS: UMA REVISÃO. CuidArte Enfermagem, [S.I], v. 1, n. 11, p. 105-113, 2017.

[9] LOUREIRO, R. J. et al. O uso de antibióticos e as resistências bacterianas: breves notas sobre a sua evolução. Revista Portuguesa de Saúde Pública, [S.L.], v. 34 , n. 1, p. 77-84, jan. 2016.

[10] MATOS, C.; CUNHA, I. N. About a Portuguese community's awareness of antibiotic use. Biopharmaceutical Sciences, v. 11, n. 1, p. 80-100, 2014.

[11] SANTOS, Maria José Amador dos; PORCY, Claude; MENEZES, Rubens Alex de Oliveira. Etiologia e perfil de resistência bacteriana em uroculturas de pacientes atendidos em um hospital público de Macapá-Amapá, Brasil. Um estudo transversal. Diagn Tratamento, V. 4, n. 24, p. 135-152, 2019.

[12] SPINKS, Anneliese; GLASZIOU, Paul P; MAR, Chris B del. Antibiotics for sore throat. Cochrane Database of Systematic Reviews, [S.L.], p. 1-78, 5 Nov. 2013.

[13] TEXEIRA, B. C., CAMPOS, L. S., CASALINI, C. E. C. Perfil de automedicação em estudantes de ensino superior: impacto na resistência bacteriana. Revista Saúde Integrada, [S.I], v.12, n.24, 2019.

[14] TRABULSI, Luiz Rachid; ALTERTHUM, Flavio. MICROBIOLOGIA. 6. ed. São Paulo: Atheneu, 2015. $912 \mathrm{p}$.

[15] TUYISHIMIRE, Jacques; OKOYA, Funmbi; ADEBAYO, Adebisi Yusuff; HUMURA, Fabrice; LUCERO-PRISNO, Don Eliseo. Assessment of selfmedication practices with antibiotics among undergraduate university students in Rwanda. Pan African Medical Journal, [S.L.], v. 33, p. 1-7, 2019. 